\title{
Korupsi Siemens Aktiengesellschaft dalam United Nations-Oil For Food Programme (Un-Offp) di Irak
}

\author{
Sheiffi Puspapertiwi \\ Program Pascasarjana Hubungan Internasional, Universitas Gadjah Mada
}

\begin{abstract}
Corruption, as a nontraditional form of crime, occurred when power is abused to gain certain favours for individuals or parties at the expense of the rest. Siemens Aktiengesellscahft (Siemens AG) bribery case is the biggest company corruption revealed in history, in which the company had been convicted guilty for giving bribes to governments in many countries, from developing to developed countries. In Iraq, Siemens AG was proved guilty for giving bribes to Saddam Hussein regime during its involvement in United Nation Oil for Food Programme (UN-OFFP) in 200O-2002. This research is conducted to understand causing factors of such action by employing qualitative data for further analysis. Research finding shows that corruption in UNOFFP involving three institutions: Siemens AS, Saddam Hussein regime, and UN, was occurred due to pragmatism in pursuing economic motive which encouraged by accommodative culture and enabled by weak law enforcement.
\end{abstract}

Keywords: corruption, bribery, Siemens, UN-OFFP

\begin{abstract}
Abstrak
Korupsi, sebagai salah satu bentuk kejahatan non tradisional, terjadi ketika kekuasaan disalahgunakan untuk memperoleh keuntungan pribadi atau kelompok di atas kepentingan pihak-pihak lain. Kasus penyuapan oleh Siemens Aktiengesellschaft (Siemens AG) merupakan kasus korupsi perusahaan terbesar dalam sejarah, di mana perusahaan tersebut terbukti bersalah karena memberikan suap kepada pemerintah di berbagai negara. Di Irak, Siemens AG terbukti bersalah karena memberikan suap kepada rezim Saddam Hussein selama keikutsertaannya dalam Program PBB 'Minyak untuk Makanan' di tahun 200o-2002. Penelitian ini dilakukan untuk memahami faktor penyebab aktivitas tersebut dengan menggunakan data kualitatif untuk dianalisis lebih lanjut. Penemuan penelitian menunjukkan bahwa korupsi dalam UN-OFFP yang melibatkan tiga institusi: Siemens AG, rezim Saddam Hussein, dan PBB, terjadi karena pragmatisme dalam memenuhi motif ekonomi yang didorong oleh budaya yang akomodatif serta dimungkinkan oleh lemahnya mekanisme penegakan hukum.
\end{abstract}

Kata kunci: korupsi, penyuapan, Siemens, UN-OFFP 
Siemens Aktiengesellschaft (Siemens AG) adalah sebuah perusahaan multinasional Jerman yang bergerak di bidang konstruksi, komunikasi, peralatan medis, serta transportasi. Salah satu proyek yang ditangani Siemens AG adalah pengadaan barang dalam Program PBB 'Minyak untuk Makanan' (United NationsOil for Food Program, UNOFFP). Setelah UN-OFFP berakhir pada tahun 2003, dilakukan evaluasi program yang mengungkap berbagai tindak penyuapan dalam jumlah besar terhadap rezim Saddam Hussein oleh perusahaan partner UN-OFFP, termasuk diantaranya adalah Siemens AG yang terbukti telah membayar suap kepada pejabat-pejabat Irak terkait dengan keikutsertaannya dalam program tersebut (The United States District Court for the District of Columbia, 2008). Kasus tersebut menarik untuk diteliti terkait empat fakta berikut.

Pertama, kasus penyuapan oleh Siemens AG merupakan kasus penyuapan peruasahaan terbesar yang pernah terungkap. Siemens AG diketahui telah mengeluarkan uang sejumlah USD1,36 milyar dari Maret 2001 hingga menjelang tahun 2007 untuk mendapatkan kontrak dari pemerintah di berbagai negara tempatnya beroperasi.Salah satu kasus yang disidangkan melibatkan empat anak perusahaan milik Siemens AG, yaitu Siemens Perancis, Siemens Turki, Osram Timur Tengah, dan Gas Turbine Technologies SpA (GTT) yang melakukan penyuapan kepada Pemerintah Irak terkait dengan keikutsertaannya dalam program UNOFFP(Foreign Corrupt Practice Act Reporting Centre, 2008).

Kedua, sebagai negara basis dari Siemens AG, Jerman telah memiliki Gesetz zur Bekämpfung der Korruption sebagai undangundang anti-korupsi.Selain itu, Jerman juga terikat dalam perjanjian anti-korupsi internasional seperti European Union Bestechungsgesetz dan Convention on Combating Bribery of Foreign Public Officials in International Business Transaction(OECD, 2011). Siemens AG sebagai corporate citizen Jerman memiliki kewajiban untuk menaati hukum yang ditetapkan oleh pemerintah, termasuk perjanjian-perjanjian internasional yang diratifikasi oleh parlemennya. Namun kenyataannya, Siemens AG telah melanggar hukum, baik nasional, ekstra teritorial, maupun internasional terkait dengan korupsi penyuapan yang dilakukan.

Ketiga, Jerman dinilai bersih dari tindak korupsi. Penilaian ini mengacu pada laporan yang dikeluarkan oleh Transparency International (TI), sebuah organisasi yang memiliki perhatian terhadap korupsi. Di tahun 2013, Jerman berada pada peringkat kedua belas dari 177 negara (Transparency International, 2013). Sementara dalam Bribe Payers Index (BPI) yang merupakan peringkat negara berdasarkan penyuapan yang dilakukan oleh perusahaan multinasionalnya, pada tahun 2011 Jerman menduduki peringkat keempatdari 28 negara, berada di bawah Belanda, Swiss, dan Belgia (Transparency International, 2011).

Keempat, UN-OFFP memiliki mekanisme penjamin transparansi dan akuntabilitas dengan melibatkan institusi maupun pihak independen lain dalam implementasi (Volcker, et al., 2005c). Dengan adanya badan-badan pemeriksa tersebut, diharapkan UN-OFFP dapat terbebas, atau setidaknya kecil angka kejadiannya, dari tindak korupsi. Tetapi, dalam laporan yang dikeluarkan badan pemeriksa ditemukan banyak transaksi gelap, termasuk penyuapan seperti yang dilakukan oleh Siemens AG.

Keempat fakta yang merupakan deviasi dari logika umum tersebut menjadikan kasus penyuapan oleh Siemens AG dalam UNOFFP di Irak pada tahun 2000-2002 layak untuk diteliti lebih lanjut. Terkait dengan hal tersebut, tulisan ini berupaya untuk mengetahui penyebab terjadinya korupsi oleh Siemens AG dalam UN-OFFP pada tahun 2000-2002. Untuk memeroleh jawabannya, tulisan ini menggunakan pendekatan konseptual "korupsi" untuk menganalisis data kualitatif yang telah dikumpulkan.

Penelitian-penelitian yang dilakukan sebelumnya terkait dengan evaluasi UN-OFFP seperti dalam Katzman (2003) serta Christoff (2004) untuk Senat AS serta laporan kompherehensif yang ditulis oleh Volcker et al (2005) untuk PBB telah mengelaborasikan berbagai pelanggaran yang terjadi, termasuk penyuapan dan perdagangan minyak ilegal yang dilakukan oleh rezim Saddam Hussein. 
Penjelasan telah memberikan pemahaman dari perspektif keuangan maupun hukum, di mana tulisan ini nantinya bermaksud untuk melengkapi dengan menggunakan perspektif ekonomi-politik dalam meninjau penyebab korupsi penyuapan yang terjadi secara spesifik antara Pemerintah Irak dan Siemens AG.

Dari hasil penelitian yang dilakukan, diketahui bahwa korupsi oleh Siemens AG dalam UN-OFFP terjadi karena adanya pragmatisme dalam memenuhi motif ekonomi baik dari pihak penawar dan peminta, yang tidak disertai implementasi peraturan maupun pengawasan yang efektif dari institusi terkait. Temuan tersebut sesuai dengan argumen Gray dan Kaufmann, yang menyatakan bahwa korupsi, terutama di negara berkembang seperti Irak, disebabkan oleh adanya motivasi yang didorong kondisi ekonomi, lemahnya akuntabilitas institusi politik, serta tidak berjalannya fungsi institusi pengawas yang independen (Gray \& Kaufmann, 1998: 9).

Selanjutnya, tulisan ini akan mengelaborasikan data-data yang ditemukan untuk membuktikan argumen mengenai penyebab korupsi Siemens AG ke dalam tiga bagian. Bagian pertama akan mendeskripsikan UN-OFFP sebagai dasar untuk memahami kinerja program tersebut. Bagian kedua menjelaskan aspek korupsi dalam tindakan yang dilakukan oleh Siemens AG. Kemudian dengan memahami kedua bagian tersebut, pembahasan beranjak ke bagian tiga yang akan mengelaborasi data-data pendukung untuk menjawab penyebab kasus korupsi yang dibahas.

\section{United Nation Oil for Food Program (UN-OFFP)}

UN-OFFP merupakan program PBB yang dilaksanakan di Irak sebagai respon terhadap memburuknya kondisi ekonomi dan sosial masyarakat Irak pasca embargo ekonomi yang dijatuhkan kepada rezim Saddam Hussein terkait aksi invasi Irak ke Kuwait. Bedasarkan resolusi tersebut, negara-negara anggota PBB dilarang melakukan sebagian besar aktivitas perdagangan ataupun finansial dengan Irak (Christoff, 2004). Dalam program tersebut, Pemerintah Irak hanya memiliki wewenang untuk mengajukan proposal pembelian barang kebutuhan kemanusiaan serta memilih mitra dagang. Persetujuan dan pengalokasian dana dilakukan oleh PBB dengan Banque Nationale de Paris (BNP) sebagai mitra perbankan yang menampung semua dana hasil penjualan minyak Irak serta membayar pengeluaran kebutuhan kemanusiaan Irak (Volcker, et al., 2005c).

Puncak komando PBB di Irak dipegang oleh Office of Iraq Program (OIP) yang bertanggung jawab kepada Komite 661. Komite 661 sendiri beranggotakan perwakilan dari anggota Dewan Keamanan Tetap PBB yang bertugas mengawasi dan menginspeksi implementasi saksi ekonomi; menelaah dan menyetujui harga maupun mekanisme penjualan minyak; menyetujui kontrak penjualan; serta menelaah dan menyetujui harga serta jenis barang yang diimpor oleh Pemerintah Irak. Mengingat UN-OFFP melibatkan dana dengan jumlah besar, program tersebut dilengkapi dengan badan pemeriksaan keuangan, antara lain Internal Auditor Division (IAD) yang bertugas melakukan pemeriksaan keuangan dan memberikan rekomendasi untuk perbaikan sistem secara internal, serta badan pemeriksa eksternal Board of Auditors (BOA) dan Joint Inspection Unit (JIU) (Volcker, et al., 2005c).

Secara de jure, UN-OFFP dihentikan pada 22 Mei 2003 melalui Resolusi DK PBB 1472 terkait dengan invasi AS dan sekutunya pada Maret 2003 (Office of the Iraq Programme Oil for Food, 2003). Berakhirnya UN-OFFP menandai dimulainya tahap evaluasi program. Dari hasil penyelidikan yang dilakukan, ditemukan fakta bahwa pemerintah Irak telah menerima pendapatan gelap dari aktivitas penyelundupan minyak dan transaksi impor barang kebutuhan kemanusiaan (lihat Tabel 1).

Dalam UN-OFFP, terdapat lima entitas perusahaan Siemens AG yang terlibat dalam sejumlah proyek untuk beberapa kebutuhan kemanusiaan di Irak (lihat Tabel 2 berikut).

Kemudian terkait dengan skema pembayaran kembali yang dikenakan oleh pemerintah Irak terhadap perusahaanperusahaan importir yang bekerjasama dengannya, Siemens AG juga diwajibkan membayar baik biaya transportasi darat 
maupun biaya 'pelayanan-setelah-penjualan'

(lihat Tabel 3).

Tabel 1. Pendapatan Gelap Pemerintah Irak dalam UN-OFFP

\begin{tabular}{|c|c|c|}
\hline Sumber Pendapatan Gelap & $\begin{array}{c}\text { Jumlah } \\
\text { (dalam juta) }\end{array}$ & Keterangan \\
\hline Penyelundupan minyak & USD 8.400 & Senilai dengan 650 juta barel \\
\hline Penambahan biaya (surcharge) & USD 229 & $\begin{array}{l}\text { Penambahan biaya dikenakan } \\
\text { dalam setiap penjualan } \\
\text { minyak dengan besaran } \\
\text { USDo,1 hingga o,5 per barel. }\end{array}$ \\
\hline $\begin{array}{l}\text { Pembayaran Kembali (kickback) } \\
\text { - } \quad \text { Biaya Transportasi } \\
\text { - } \quad \text { Biaya 'pelayanan-setelah-penjualan' }\end{array}$ & $\begin{array}{cr}\text { USD } & 530 \\
\text { USD } & \mathbf{1 . 0 2 0}\end{array}$ & $\begin{array}{l}\text { Pembayaran kembali } \\
\text { dikenakan untuk setiap } \\
\text { kontrak impor barang } \\
\text { kebutuhan kemanusiaan }\end{array}$ \\
\hline Jumlah & USD 10.179 & \\
\hline
\end{tabular}

Sumber: Independent Inquiry Committee into the United Nations Oil-for-Food Programme (2005)

Tabel 2. Keterlibatan Perusahaan Afiliasi Siemens AG dalam UN-OFFP

\begin{tabular}{|c|c|c|c|c|c|}
\hline $\begin{array}{c}\text { Nama } \\
\text { Perusahaan }\end{array}$ & Asal & $\begin{array}{l}\text { Periode } \\
\text { Kontrak }\end{array}$ & $\begin{array}{l}\text { Jumlah } \\
\text { Kontrak }\end{array}$ & $\begin{array}{c}\text { Nilai } \\
\text { Kontrak }\end{array}$ & $\begin{array}{c}\text { Kerjasama } \\
\text { Kontrak }\end{array}$ \\
\hline $\begin{array}{l}\text { Siemens AG } \\
\text { Medical } \\
\text { Solutions }\end{array}$ & $\begin{array}{l}\text { Austria } \\
\text { dan } \\
\text { Jerman }\end{array}$ & - & 42 & $\begin{array}{r}\text { USD } \\
88.083 .843\end{array}$ & $\begin{array}{l}\text { Pengadaan dan } \\
\text { perawatan peralatan } \\
\text { medis serta teknologi } \\
\text { penunjangnya }\end{array}$ \\
\hline Siemens SAS & Perancis & $\begin{array}{l}\text { Januari } 2000 \text { - } \\
\text { April } 2001\end{array}$ & 18 & $\begin{array}{r}\text { USD } \\
47.918 .636\end{array}$ & $\begin{array}{l}\text { Perbaikan dan } \\
\text { perawatan } \\
\text { pembangkit listrik }\end{array}$ \\
\hline $\begin{array}{l}\text { Siemens } \\
\text { Sanayi Ve } \\
\text { Ticaret AS }\end{array}$ & Turki & $\begin{array}{l}\text { September } \\
2000-\text { Juni } \\
2002\end{array}$ & 7 & $\begin{array}{r}\text { USD } \\
51.291 .305\end{array}$ & $\begin{array}{l}\text { Pengadaan energi } \\
\text { dan peralatan } \\
\text { kelistrikan }\end{array}$ \\
\hline $\begin{array}{l}\text { Osram Timur } \\
\text { Tengah }\end{array}$ & $\begin{array}{l}\text { Uni } \\
\text { Emirat } \\
\text { Arab }\end{array}$ & $\begin{array}{l}\text { Februari } 2000 \\
\text { - Juni } 2002\end{array}$ & 8 & $\begin{array}{r}\text { USD } \\
1.513 .870\end{array}$ & $\begin{array}{l}\text { Pengadaan bola } \\
\text { lampu dan peralatan } \\
\text { listrik }\end{array}$ \\
\hline $\begin{array}{l}\text { Gas Turbine } \\
\text { Technologies } \\
\text { SpA }\end{array}$ & Italia & Juni 2001 & 1 & USD 605.232 & $\begin{array}{l}\text { Pengadaan turbin } \\
\text { pembangkit listrik }\end{array}$ \\
\hline
\end{tabular}

Sumber:Independent Inquiry Committee into the United Nations Oil-for-Food Programme (2005) dan The United States District Court for the District of Columbia (2008)

Tabel 3. Penyuapan oleh Siemens AG terhadap Pemerintah Irak

\begin{tabular}{lcc}
\hline \multicolumn{1}{c}{ Nama Perusahaan } & $\begin{array}{c}\text { Suap Diketahui } \\
\text { telah } \\
\text { Dibayarkan }\end{array}$ & Perantara \\
& USD 489 & \\
\hline Siemens AG Medical Solution & USD 321.256 & Perusahaan Paraguay di Yordania \\
Siemens SAS & USD 202.140 & Perusahaan Paraguay di Yordania \\
Siemens Turki & USD 85.673 & Agen Berkewarganegaraan Irak \\
Osram Timur Tengah & USD 2.000 & Agen Berkewarganegaraan Irak
\end{tabular}

Sumber: Independent Inquiry Committee into the United Nations Oil-for-Food Programme (2005) dan The United States District Court for the District of Columbia (2008) 
Pembayaran-pembayaran tersebut dilakukan dengan mekanisme seperti yang dapat dilihat dalam Gambar 1 berikut.

Gambar 1. Skema Pembayaran Kembali oleh Siemens AG

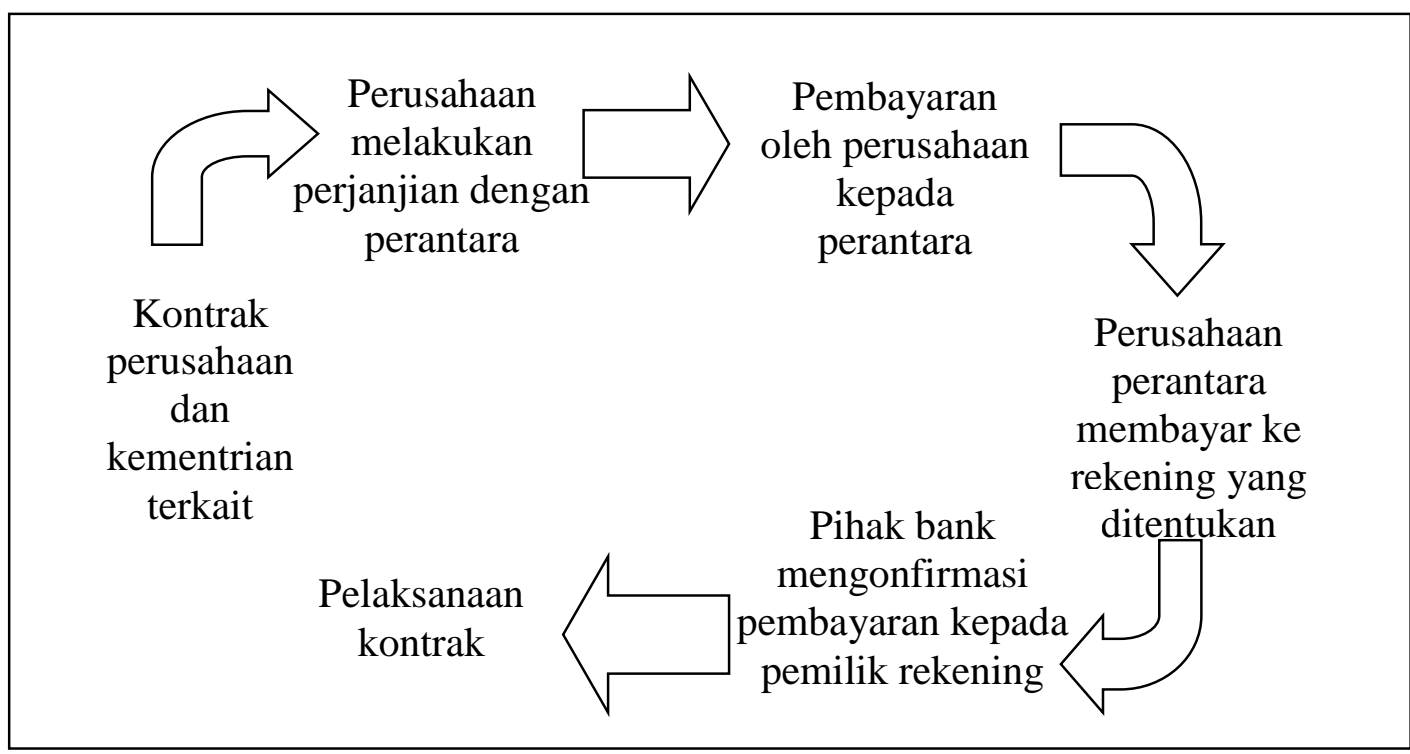

Sumber: The United States District Court for the District of Columbia (2008)

\section{Penyuapan Siemens AG sebagai Kasus Korupsi}

Korupsi tidak memiliki definisi tunggal, meskipun dari berbagai argumen yang telah dikemukakan oleh para ahli setidaknya dapat ditemukan dua prinsip utama untuk mengklasifikasikan sebuah tindakan sebagai korupsi. Pertama, adanya peraturan yang dilanggar, baik secara hukum, moral, maupun agama. Kedua, penyalahgunaan untuk kepentingan pribadi. Keuntungan yang diperoleh tidak selalu dalam bentuk materi, tetapi bisa juga dalam bentuk non-materi seperti kekuasaan dan akses. Kepentingan pribadi juga tidak selalu merujuk pada diri pelaku korupsi saja, tetapi juga dapat berarti keluarga, relasi, kelompok, hingga suku.

Korupsi memiliki berbagai wajah, salah satunya dalam bentuk penyuapan yang karakter utamanya adalah adanya perpindahan materi. Dalam praktek bisnis, pemberian suap memiliki garis batas yang kabur dengan tip (grease payment). Meskipun demikian, secara teoritis dapat dinyatakan bahwa kesepakatan suap terjadi sebelum kontrak dilaksanakan dengan maksud mempengaruhi keputusan atau perilaku penerimanya, sementara tip diberikan dalam nilai relatif kecil setelah penerima melakukan tindakan tertentu untuk pemberi materi. Dalam budaya tertentu, tip merupakan wujud dari penghargaan dan merupakan hal yang wajar dalam praktek bisnis (Fritzsche, 2005: 11-12). Meskipun penyuapan secara umum dianggap sebagai korupsi dalam berbagai budaya,terdapat perbedaan parameter dan tingkat toleransi untuk budaya yang berbeda (Hooker, 2009: 254). Perbedaan tersebut mengarah pada berlakunya konsensus, yang juga dikenal sebagai hukum positif.

Dari perspektif hukum positif internasional, kasus penyuapan yang dilakukan oleh anak perusahaan Siemens kepada Pemerintah Irak tidak termasuk dalam klasifikasi tip. Karakter dari pemberian tip dalam dunia bisnis adalah berjumlah kecil serta tidak mengganggu aktivitas bisnis (Frizsche, 2005: 11-12). Dalam kasus Siemens, akumulasi pembayaran kembali (kickback) terhadap pemerintah Irak berjumlah lebih dari USD600.00o dari kontrak yang nilainya hampir sebesar USD20o juta. Meskipun tidak ada konsensus mengenai definisi "jumlah kecil” untuk mengukur rasio kepantasan tip 
sehingga poin tersebut tidak relevan dalam meninjau kasus Siemens, pemberian materi oleh anak perusahaan Siemens memenuhi unsur penyuapan dalam aspek waktu kesepakatan serta tujuan.

Berdasarkan alur suap yang ditunjukkan dalam Gambar 1, dapat diketahui bahwa kesepakatan untuk memberi materi terjadi sebelum pelaksanaan kontrak. Berdasarkan aturan dalam hukum bisnis, kontrak berlaku semenjak penandatanganan dokumen. Meskipun demikian, momen krusial dalam kontrak adalah tahap implementasi, yang terdapat keputusan untuk melanjutkan atau menghentikan hubungan dagang dibuat oleh pembeli, yaitu Pemerintah Irak. Hal tersebut menjadikan Pemerintah Irak memegang kendali untuk membatalkan kontrak secara sepihak dengan tidak menerima barang yang dikirim perusahaan jika diketahui perusahaan tersebut gagal menjalankan ketentuan suap yang ditetapkan.

Kondisi tersebut mengarah kepada pemenuhan unsur maksud pemberian, yaitu untuk memengaruhi keputusan. Materi yang diberikan oleh lima anak perusahaan Siemens merupakan upaya yang dilakukan agar Pemerintah Irak tetap melanjutkan kesepakatan kontrak dengannya, sehingga menjadikan pemberian materi sebesar USD600.00o oleh Siemens AG terhadap Pemerintah Irak sebagai tindakan penyuapan. Beranjak dari hal tersebut, maka kasus Siemens AG juga dapat ditelaah dengan menggunakan pendekatan yang lebih luas, yaitu korupsi, yang memiliki dua prinsip utama mengenai pelanggaran serta keuntungan bagi minoritas yang mendatangkan kerugian bagi kelompok mayoritas.

Aspek teknis mengenai pelanggaran hukum dalam kasus penyuapan oleh Siemens AG dapat ditinjau dari dua perundangan dan satu peraturan. Perundangan pertama yang dilanggar adalah hukum nasional Jerman mengenai penyuapan terhadap pejabat asing. Sesuai amandemen Undang-undang Antikorupsi tahun 2002, Jerman telah mengklasifikasikan penyuapan oleh sektor privat baik terhadap pejabat maupun sesama sektor privat asing sebagai pelanggaran hukum. Perundangan kedua adalah hukum ekstra teritorial, di mana Siemens telah melanggar Foreign Corrupt Practices Act (FCPA). FCPA merupakan produk hukum AS yang memiliki yurisdiksi ekstrateritorial yang menjangkau seluruh perusahaan yang terdaftar dalam NYSE. Siemens sendiri terdaftar di NYSE sejak 12 Maret 2001 (The United States District Court for the District of Columbia, 2008). Dengan melihat bahwa Siemens AG tergabung dalam daftar perusahaan penyedia dalam OFFP pada tahun 2000-2002, maka dapat dinyatakan bahwa Siemens AG telah melanggar FCPA untuk praktek korupsi penyuapan yang dilakukan sejak terdaftar dalam NYSE.

Selain pelanggaran terhadap dua perundangan tersebut, kasus penyuapan oleh Siemens AG juga telah melanggar peraturan UN-OFFP. Pertama, larangan kepada pihak importir untuk melakukan pembayaran langsung maupun melalui perantara kepada pemerintah Irak, sementara Siemens membayar biaya transportasi dan 'biayasetelah-pelayanan' melalui perantara perusahaan Paraguay dan warga negara Irak. Kedua, pemberian tip diperkenankan jika diberikan dalam mata uang Dinar Irak. Dalam prakteknya, perusahaan-perusahaan afiliasi Siemens membayar lebih dari USD600.00o ke rekening-rekening pemerintah Irak. Ketiga, kerahasiaan dengan tidak menginformasikan pembayaran biaya-biaya tambahan baik oleh Siemens maupun perusahaan lain kepada PBB juga merupakan pelanggaran.

Selain pelanggaran hukum, penyuapan dalam OFFP juga telah melanggar norma "kepentingan bersama berada di atas kepentingan pribadi maupun golongan". Penyuapan oleh Siemens dan perusahaanperusahaan lainnya telah merugikan OFFP sebesar USD1,8 milyar, yang seharusnya menjadi hak rakyat Irak. Uang tersebut memang kembali ke Irak, namun hanya dinikmati oleh sekelompok kecil orang, terutama mereka yang berada dalam lingkaran patron-klien Saddam Hussein.

Tindakan tersebut memenuhi kriteria kedua korupsi, yaitu penyalahgunaan wewenang untuk keuntungan pribadi. Penggunaan pertama dari dana ilegal tersebut adalah untuk pengembangan intelijen dan militer, meskipun telah dilarang dalam UN- 
OFFP (Abdullah, 2006: 27). Kedua, pemberian insentif bagi klien dan keluarga Saddam Hussein berupa pemberian tanah; kredit perumahan; kemudahan akses terhadap bahan bangunan, barang elektronik, dan bahan makanan; serta pelayanan medis gratis di rumah sakit pemerintah sementara rakyat mengalami kesulitan dalam mengakses fasilitas-fasilitas tersebut (Abdullah, 2006: 8283). Sebagai akibat dari penggelapan dana kemanusiaan tersebut, telah terjadi kerugian publik seperti yang dapat dilihat dari pencapaian program. Secara umum, wilayah Irak Utara yang dikelola PBB mengalami peningkatan di bidang pemenuhan nutrisi, penyediaan sarana kesehatan, pendidikan, dan pemberdayaan masyarakat di bidang pertanian (United Nations, n.d.). Sementara itu, wilayah Irak Tengah dan Selatan yang dikelola pemerintah tidak mencapai indikator kesejahteraan sebaik di wilayah utara (SalemPickartz, 2003).

Dengan mengaitkan kesenjangan kesejahteraan antar wilayah di Irak serta penggunaan dana hasil suap yang telah diungkapkan sebelumnya, maka dapat dibuktikan bahwa penyuapan yang dilakukan oleh partner dagang UN-OFFP, termasuk diantaranya Siemens AG, terhadap Pemerintah Irak merupakan tindakan korupsi karena kesejahteraan sebagian kecil warga Irak diperoleh melalui pengabaian pemenuhan hak sebagian besar kelompok masyarakat lainnya. Korupsi sendiri hanya dapat terjadi jika permintaan bertemu dengan penawaran, dalam kondisi tertentu. Berikut akan disampaikan prakondisi sebagai cikal bakal kondisi tertentu yang dimaksud, serta unsur penawaran dan permintaan dalam kasus penyuapan oleh Siemens AG di Irak.

\section{Penyebab Korupsi Penyuapan Siemens AG dalam UN-OFFP}

Melalui pembahasan sebelumnya, telah diketahui bahwa penyuapan yang dilakukan oleh Siemens terhadap rezim Saddam Hussein melalui berbagai skema pembayaran yang ditetapkan Pemerintah Irak merupakan tindakan korupsi. Dalam kasus tersebut, dapat diperoleh gambaran bahwa batasan korupsi terkait erat dengan norma dan peraturan yang berlaku. Keduanya berfungsi untuk membentuk perilaku aktor yang terlibat, baik melalui tekanan dan mekanisme hukuman atas pelanggaran maupun insentif untuk kepatuhan. Dari logika tersebut, dapat dinyatakan bahwa korupsi dapat terjadi jika tidak ada institusi yang efektif dalam pembentuk perilaku aktor-aktornya. Selanjutnya, tulisan ini akan mengelaborasi penyebab terjadinya korupsi Siemens AG dalam OFFP ditinjau dari tiga aktor yang terlibat, yaitu: PBB, Siemens AG, dan rezim Saddam Hussein.

Krisis Legitimasi PBB sebagai Kesempatan Berkembangnya Korupsi di Irak

Sebagai institusi pelaksana OFFP, PBB melalui OIP memiliki tanggung jawab besar untuk mengontrol perilaku aktor-aktor yang terlibat, terutama Pemerintah Irak sebagai aktor utama dalam program tersebut. Meskipun demikian, otoritas yang dimiliki PBB tidak berasal dari legitimasi internal karena kedudukannya di Irak didasarkan pada resolusi Dewan Keamanan. Dalam program tersebut, Irak tetap negara berdaulat dengan pemerintahan yang memiliki legitimasi politik atas wilayahnya sementara perusahaan multinasional yang menjadi mitra dagang merupakan entitas ekonomi yang bekerja berdasarkan prinsip utilitas dan keuntungan. Dengan melihat sifat dari aktor-aktor yang terlibat, dapat diketahui bahwa ketiganya memiliki posisi yang berbeda dalam melihat OFFP.

Sementara itu, legitimasi dibutuhkan untuk mengikat komitmen dari anggotanya untuk berperilaku sesuai dengan nilai dan norma bersama yang berlaku dalam sebuah institusi (Peters, 2001: 29-30). Kondisi tersebut menjadi tantangan bagi PBB dalam implementasi maupun pengawasan peraturan anti korupsi bagi Pemerintah Irak, yang dalam prakteknya dimanfaatkan oleh rezim Saddam Hussein untuk melakukan transaksi korup dalam UN-OFFP dengan mitra-mitra dagangnya.

Sebagai institusi yang tidak memiliki legitimasi politik di Irak, PBB hanya dapat mengandalkan keselarasan kepentingan dari aktor yang terlibat dalam menjalankan OFFP. PBB sebagai institusi juga tidak memiliki kemampuan untuk menjatuhkan sanksi bagi 
pelanggar peraturan. Dalam konteks ini, Komite 661 sebagai otoritas tertinggi OFFP tidak memiliki kewenangan eksekutif sehingga tidak dapat memberikan sanksi kepada pelanggar peraturan, kecuali menyangkut penyelundupan senjata. Jika Komite 661 mengetahui telah terjadi pelanggaran atas pelaksanaan program, maka tindakan yang dapat dilakukan hanyalah melaporkannya kepada DK PBB untuk kemudian diproses lebih lanjut dan sudah tidak menjadi tanggung jawab Komite 661 lagi.

Tidak hanya mengalami krisis legitimasi secara struktural, posisi PBB di Irak bertambah sulit dengan adanya pejabat korup dalam programnya. Benon Sevan, Direktur Eksekutif OIP, dianggap telah lalai dalam menjalankan fungsi pengawasan sanksi, menahan bukti terjadinya pembayaran gelap yang diminta oleh pemerintah Irak dari Komite 661, dan tidak memastikan Contracts Processing dan Monitoring Division memiliki sumber daya yang memadai untuk menjalankan tugasnya. Kesalahan-kesalahan itu disebut berkaitan dengan kedekatan hubungan antara Sevan dan pejabat senior Irak. Sevan diduga juga telah menerima suap dari pemerintah Irak agar tidak melaporkan penyelewengan tersebut kepada Komite 661 atau otoritas lain yang lebih tinggi (Volcker, et al., 2005c).

Meskipun memiliki keterbatasan legitimasi, PBB tetap berupaya menjalankan fungsi institusionalnya dalam mencegah terjadinya korupsi dalam OFFP sebagai deviasi perilaku aktor-aktor yang terlibat. Upaya tersebut diwujudkan dengan adanya struktur pemeriksa yang direpresentasikan oleh IAD, BOA, dan JIU. Meskipun demikian, kompleksitas program yang bertambah dari tahun ke tahun serta kurangnya sumber daya manusia ditengarai sebagai hambatan internal yang ikut memperbesar kesempatan untuk melanggar peraturan anti-korupsi OFFP (Volcker, et al., 2005c).

Dari penjelasan di atas, dapat dikatakan bahwa fungsi institusional yang dijalankan PBB terkait dengan pembatasan perilaku korup baru sebatas pembuatan, pelaksanaan, serta pengawasan regulasi secara teknis, tanpa dapat memberikan implikasi substantif terhadap perilaku aktor yang terlibat karena adanya krisis legitimasi dalam posisinya sebagai institusi otoritas program. Kelemahan dari sisi penegakan regulasi inilah yang kemudian menjadi prakondisi bagi pemerintah Irak untuk mengekstraksi dana kemanusiaan melalui suap yang diminta dari perusahaan importir, termasuk Siemens AG lewat kelima anak perusahaannya.

\section{Motif Ekonomi dan Budaya Perusahaan sebagai Justifikasi Penawaran Suap oleh Siemens $A G$}

Secara garis besar, penawaran suap oleh Siemens AG disebabkan oleh motif ekonomi yang dilegitimasi oleh alasan historis dan budaya perusahaan. Motif ekonomi yang menjadi prinsip dasar beroperasinya sebuah perusahaan membentuk norma dan sejarah perusahaan. Di kemudian hari, sejarah menjadi referensi perusahaan ketika berada dalam situasi dilematis, misalnya menghadapi mitra bisnis yang korup. Siemens AG sebagai salah satu perusahaan multinasional merupakan bukti nyata dari penerapan prinsip utilitas dan keuntungan sebagai nilai dasar yang berlaku bagi entitas ekonomi. Dalam perjalanan sejarahnya, perusahaan tersebut telah beradaptasi dengan situasi agar dapat tetap bertahan dalam kompetisi bisnis yang semakin ketat dari masa ke masa.

Siemens AG pada awalnya merupakan perusahaan perlengkapan dan peralatan militer milik Nazi pada masa Perang Dunia II. Ketika perang berakhir, Siemens mengalami kerugian hingga memutuskan untuk memperluas pasar ke negara berkembang sementara ekonomi domestik di Jerman dalam masa pemulihan(Siemens, 2011).Ketika beralih ke pasar negara berkembang, Siemens harus melakukan penyesuaian dengan budaya setempat, termasuk di antaranya mengikuti kebiasaan "saling memberi". Pada akhirnya, kebiasaan tersebut menjadi budaya yang terinstitusionalisasi dalam melakukan kontrak bisnis, seperti dibentuknya pos anggaran nützliche aufwendungen (pengeluaran serbaguna)yang pada prakteknya merupakan pos anggaran untuk membayar suap(The United States District Court for the District of Columbia, 2008).

Seiring dengan meningkatnya kepedulian publik terhadap etika bisnis 
menyangkut praktek suap, pada tahun 1998 Siemens AG ikut melengkapi struktur organisasinya dengan komite etik antipenyuapan yang disebut $Z$ circular dan Corporate Officer for Complience (COC) pada 2001. Meskipun demikian, praktek suap terus dilakukan oleh anak perusahaan Siemens AG dalam praktek bisnisnya, terutama di negaranegara berkembang (The New York Times Company, 2008)yang memang memiliki tendensi rentan terhadap praktek korupsi(Gray \& Kaufmann, 1998: 9).

Dalam proyek UN-OFFP, Siemens AG memperoleh 76 kontrak dengan nilai mencapai USD189.412.886(Volcker, et al., 2005b). Dari jumlah tersebut, Siemens Perancis, Siemens Turki, Osram Timur Tengah, dan GTT Italia memperoleh keuntungan bersih sebesar USD38.000.000(The United States District Court for the District of Columbia, 2008). Keuntungan ini signifikan mengingat pendapatan Siemens AG secara global mengalami kontraksi yang pada tahun 1999200omencapai USD8,8 triliun kemudian turun drastis menjadi USD2 triliun pada tahun 2000-2001. Sementara itu, diketahui bahwa pada Januari 2000 Siemens Perancis mulai memasuki kompetisi bisnis dalam UN-OFFP, yang kemudian diikuti oleh Osram Timur Tengah pada Februari 2000, Siemens Turki pada September 2000, dan GTT Italia pada Juni 2001 (The United States District Court for the District of Columbia, 2008). Dari runtutan peristiwa tersebut, dapat dipahami bahwa perilaku bisnis korup Siemens AG dalam UNOFFP merupakan bagian dari upaya mempertahankan keberlangsungan perusahaan di tengah memburuknya kondisi finansial.

Uraian di atas merupakan upaya untuk menunjukkan bahwa Siemens AG sebagai entitas ekonomi memilih untuk berlaku pragmatis dalam memenuhi kepentingan bisnis berupa keuntungan. Kalkulasi dari alternatif-alternatif yang dimiliki dalam menjalankan strategi bisnis perusahaan terutama di negara-negara berkembang mengarah pada akomodasi terhadap pelanggaran etika bisnis, demi memperbesar keuntungan hingga alasan mendasar berupa mempertahankan perusahaan dari kebangkrutan. Secara spesifik dalam kasus
UN-OFFP, persyaratan suap oleh Pemerintah Irak bagi setiap perusahaan yang berdagang dengannya membuat lima anak perusahaan Siemens memiliki dua pilihan. Pertama, mematuhi etika bisnis perusahaan serta hukum yang ada di Jerman maupun AS dengan tidak menyetujui pembayaran suap, tetapi memiliki arti perusahaan akan kehilangan kesempatan memperoleh keuntungan. Kedua, mengabaikan etika bisnis maupun hukum yang berlaku, tetapi dapat berpartisipasi dalam program tersebut yang berarti kesempatan memperoleh keuntungan.

Dengan latar belakang memburuknya kondisi finansial perusahaan, kelima perusahaan tersebut secara logis akan terpacu untuk memanfaatkan semua kesempatan yang dimilikinya untuk mencegah perusahaan semakin merugi. Kondisi tersebut juga disertai dengan kenyataan bahwa norma antipenyuapan dalam perusahaan hanya sebatas kode etik tanpa kekuatan hukum yang kuat serta adanya preseden dalam sejarah perusahaan yang membenarkan suap seperti ditemukan dalam nützliche aufwendungen. Ditinjau dari kondisi eksternal, hubungan antara Siemens dengan PBB sebagai otoritas OFFP merupakan kerjasama transaksional secara tidak langsung karena kontrak kerja dinegosiasikan dan dilaksanakan dengan Pemerintah Irak. Ditinjau secara rasional, kondisi tersebut membuat Siemens lebih memprioritaskan kesesuaian dengan keinginan klien,yaitu Pemerintah Irak, yang berarti kecenderungan untuk mengabaikan peraturan anti-suap yang ditetapkan oleh PBB. Secara teknis, dana suap yang diberikan kepada Pemerintah Irak juga tidak berasal dari perusahaan karena diperoleh melalui manipulasi harga barang dalam kontrak, yang berarti berasal dari hasil penjualan minyak Irak sendiri. Dengan kata lain, Siemens AG tidak perlu mengeluarkan biaya tambahan untuk suap yang dapat mereduksi proyeksi keuntungan dari aktivitas perdagangannya dalam UN-OFFP.

Akumulasi dari pertimbanganpertimbangan tersebut mengarahkan Siemens untuk mengambil pilihan kedua dengan menerima ketentuan suap yang diberlakukan Pemerintah Irak. Meskipun Jerman dianggap sebagai negara dengan supremasi hukum dan 
perusahaan multinasionalnya bersih dari tindak korupsi penyuapan, kasus Siemens AG dalam UN-OFFP menunjukkan bahwa entitas ekonomi seperti perusahaan multinasional ataupun transnasional memiliki logika berpikir yang berbeda dengan negara sehingga keputusan yang diambilnya dapat tidak sejalan dengan kebijakan negara (Nye \& Keohane, n.d.: 337). Independensi tersebut dapat muncul akibat tuntutan yang tinggi untuk beradaptasi dengan negara tempatnya beroperasi agar dapat tetap bertahan dalam ketatnya kompetisi ekonomi global.

Dalam argumennya, Hooker (2009: 254) menyatakan bahwa pemberian materi sebagai imbalan atas manipulasi kekuasaan, atau penyuapan, memiliki parameter yang berbeda dalam setiap kebudayaan. Terkait dengan hal tersebut, Siemens AG menjadi saksi eksistensi perbedaan parameter antara negara asal dan negara tempat beroperasi, yang dipengaruhi oleh modal politik, ekonomi, dan sosial yang dimilikinya. Dalam kasus ini, perhitungan ekonomi Siemens mengarahkannya untuk mengikuti norma yang berlaku di lingkungannya berada. Kondisi tersebut juga membuktikan bahwa permintaan merupakan kekuatan pendorong dominan yang menginisiasi transaksi korupsi, yang dalam kasus UN-OFFP merujuk pada Pemerintah Irak.

\section{Budaya Politik Rezim Saddam Hussein sebagai Pendorong Permintaan Suap oleh Pemerintah Irak}

Secara umum, permintaan korupsi penyuapan oleh Pemerintah Irak kepada mitra dagang UN-OFFP, termasuk di antaranya lima anak perusahaan Siemens AG, disebabkan oleh sikap oportunis dalam memperoleh kembali kedaulatan finansial rezim yang dilatarbelakangi oleh budaya politik patronklien yang kuat. Korupsi dalam hubungan patron-klien di Irak terjadi semenjak Rezim Saddam Hussein berdiri, yang kemenangannya atas rezim incumbent diperoleh dengan "membeli" dukungan dari pengikutnya. Materialisasi dukungan politik tersebut menyebabkan Saddam Hussein harus terus menjaga ketersediaan insentif-insentif yang diberikan. Tindakan Saddam Hussein yang memberikan fasilitas mewah atau kontrak pada pejabat dan pelaku bisnis untuk memperoleh loyalitas mereka memunculkan budaya "saling memberi" di kalangan elit politik (Arnold, 2008: 90), yang juga dikenal sebagai salah satu bentuk korupsi politik.

Korupsi politik sendiri semakin berkembang ketika elit politik yang memiliki monopoli penuh dalam pembuatan kebijakan tidak menyertakan struktur yang berfungsi sebagai pembatas kebebasan dalam pembuatan kebijakan, sehingga para pengambil keputusan tidak merasa perlu mempertanggungjawabkan akuntabilitas penyelenggaraan negara kepada siapa pun, termasuk pada rakyat (Klitgaard, 1997).Hal inilah yang terjadi di Irak, mengingat fakta bahwa Irak di bawah rezim Saddam Hussein, menjadikan Saddam Hussein sebagai sebagai pusat dari segala kebijakan negara. Dari pusat kekuasaan tersebut, terdapat lingkaran orangorang di sekitar Hussein yang juga memiliki monopoli atas pembuatan kebijakan tanpa pembatasan seperti yang dapat dilakukan oleh sistem peradilan yang independen. Kontrol sosial dari masyarakat yang berfungsi sebagai pengawas jalannya pemerintahan juga ditiadakan dengan pembatasan negara terhadap hak-hak politik warganya. Akibat dari ketiadaan mekanisme check and balance tersebut, elit politik Irak dapat dengan mudah membuat kebijakan korup untuk mendatangkan keuntungan bagi kelompoknya. Keterbatasan tersebut semakin didukung oleh adanya pembatasan informasi atas kebijakankebijakan pemerintah; media yang ada di Irak lebih banyak berfungsi sebagai alat propaganda dan indoktrinasi pemerintahan Saddam Hussein.

Akumulasi dari kondisi politik semasa Saddam Hussein berkuasa tersebut pada akhirnya menjadikan aturan tidak tertulis mengenai insentif material dalam setiap keputusan yang dibuat oleh elit politik, meskipun untuk kepentingan publik yang sepantasnya menjadi bagian dari tanggung jawabnya sebagai pejabat negara, mengakar ke dalam kehidupan politik di Irak. Kondisikondisi tersebut menurunkan parameter korupsi dan meningkatkan toleransi masyarakat Irak terhadap korupsi, yang berjalan seperti dalam siklus lingkaran, semakin menyuburkan praktek korupsi di 
kalangan elit politik. Meskipun menjadi landasan utama, budaya politik patron-klien yang memiliki toleransi tinggi terhadap praktek korupsi suap di Irak bukan satusatunya alasan bagi Pemerintah Irak dalam meminta suap kepada perusahaan mitra, termasuk Siemens AG. Di samping itu, terdapat alasan mendasar terkait dengan isu kedaulatan yang menyangkut keleluasaan menjalankan pemerintahan serta kekuasaan atas infrastruktur dan suprastruktur politik di Irak.

Terkait dengan isu kedaulatan, rezim Saddam Hussein sebagai pemerintahan sah di Irak merasa memiliki kekuasaan atas wilayah dan kekayaan alam yang terkandung di dalamnya. Meskipun dimaksudkan sebagai upaya dunia internasional untuk memberikan efek jera atas pelanggaran hukum internasional, ketentuan UN-OFFP berupa sistem finansial yang tersentralisasi di PBB dapat dianggap sebagai intervensi yang tidak menghormati kedaulatan Irak dengan mereduksi keleluasaan dan hak pemerintah untuk mengakses keuntungan dari hasil ekstraksi kekayaan alamnya. Ketentuan tersebut telah menyebabkan hilangnya kesempatan pemasukan bagi negara sementara pemerintah memerlukan sumber daya finansial untuk menunjang struktur dan legitimasi politiknya. Dengan kata lain, kondisi tersebut telah merugikan kepentingan politik rezim serta berpotensi mengganggu keberlangsungan kekuasaan rezim Saddam Hussein yang ditopang oleh budaya patronklien. Kemudian dikaitkan dengan sistem politik otoritarian yang dijalankan, pembatasan kekuasaan dalam bentuk apapun bagi rezim, terutama dalam bidang finansial dan militer, dapat dianggap sebagai intervensi ofensif terhadap kekuasaan rezim yang absolut. Akhirnya, dapat dipahami mengapa terdapat resistensi yang memunculkan besarnya tendensi pelanggaran oleh rezim Saddam Hussein dalam program UN-OFFP.

Meskipun tidak lagi memiliki otoritas finansial, Pemerintah Irak tetap memiliki kekuasaan atas pembuatan peraturan di negaranya serta kepemilikan terhadap perangkat politik maupun ekonomi yang ada di wilayahnya. Hal tersebut memberikan kesempatan bagi rezim Saddam Hussein untuk mengupayakan bagian dari keuntungan yang diperoleh melalui penjualan minyak dengan menggunakan kekuatan politik yang dimilikinya. Situasi ini kemudian dalam perspektif hukum positif korupsi diklasifikasikan sebagai penyalahgunaan kekuasaan, karena nyatanya hasil dari tindakan tersebut tidak dikembalikan kepada masyarakat Irak secara adil dan merata.

Dengan adanya motif ekonomi-politik tersebut,rezim Saddam Hussein berupaya mencari untuk memperoleh bagian dari penjualan minyak negerinya. Maka ketika dana dan kompleksitas UN-OFFP meningkat secara signifikan pada fase VI pada tahun 1999 (Volcker, et al., 2005), momen tersebut dilihat sebagai kesempatan dan ditindaklanjuti dengan penetapan memorandum yang menetapkan kewajiban pembayaran biaya transportasi dan 'biaya-setelah-pelayanan' oleh setiap perusahaan yang menandatangani kontrak kerjasama dengan Irak(Volcker, et al., 2005a).

Pada akhirnya dapat dinyatakan bahwa pemerintah Irak adalah aktor penentu terjadinya penyuapan Siemens AG dalam UNOFFP. Isu kedaulatan yang dikemas dalam kepentingan ekonomi dan dijustifikasi oleh budaya sosial-politik menjadi penyebab munculnya permintaan suap rezim Saddam Hussein terhadap mitra-mitra dagangnya, termasuk dari kelima anak perusahaan Siemens AG. Meskipun demikian, korupsi suap tersebut tidak akan terjadi hanya dengan alasan tersebut. Sebagaimana dalam hukum ekonomi, pasar, atau dalam konteks ini transaksi korupsi, hanya dapat terjadi jika permintaan bertemu penawaran dalam kondisi tertentu. Dalam konteks kasus yang dibahas, permintaan suap rezim Saddam Hussein bertemu dengan pragmatisme Siemens AG dalam memperoleh keuntungan dalam kondisi program yang lemah legitimasi institusi pelaksananya, yaitu PBB.

\section{Kesimpulan}

Dari pemaparan yang telah dilakukan, dapat diketahui bahwa korupsi penyuapan dapat dilakukan oleh siapapun, termasuk perusahaan multinasional dari negara dengan tingkat kesejahteraan dan supremasi hukum yang tinggi seperti Siemens AG dari Jerman. 
Hal tersebut mengandung makna bahwa perusahaan multinasional sebagai aktor rasional yang independen, hanya akan mengikuti ketentuan struktur politik di atasnya sepanjang ketentuan di dalamnya sejalan dengan kepentingannya.

Pemaparan pada bagian sebelumnya telah mengidentifikasi adanya penyebab utama dalam kasus korupsi penyuapan Siemens AG dalam UN-OFFP. Sisi penawaran penyuapan muncul dari Siemens AG yang memiliki motif ekonomi berupa keuntungan dan budaya perusahaan yang toleran terhadap korupsi serta didukung oleh perhitungan trade-off yang lebih menguntungkan jika mengabaikan ketentuan anti-penyuapan. Sementara itu sisi permintaan berasal dari Pemerintah Irak di mana budaya politik yang toleran terhadap korupsi penyuapan mengonstruksi alternatif dalam memperoleh kembali kedaulatan finansial negara. Meskipun demikian, perlu diingat bahwa korupsi memerlukan kondisi tertentu untuk terjadi, yang dalam kasus ini merujuk pada rendahnya penegakan peraturan UN-OFFP akibat lemahnya posisi politik PBB di Irak. Dengan mengidentifikasi faktor-faktor penyebabnya, dapat disimpulkan bahwa dalam kasus Siemens AG, penyuapan terjadi karena adanya motivasi, dijustifikasi oleh norma atau budaya, serta yang dipicu oleh adanya kesempatan untuk berperilaku korup.

\section{Daftar Pustaka}

\section{Buku}

Abdullah, T. (2006) Dictatorship, imperialism, and chaos: Iraq since 1989. Nova Scotia: Fernwood Publishing Ltd..

Arnold, J. R. (2008) Saddam Hussain's Iraq. Minneapolis: Twenty-First Century Books.

Frizsche, D. J. (2005) Business ethics: aglobal and managerial perspective. Singapore: McGraw-Hill.

Peters, B. G. (2001) Institutional theory in political science: the new institutionalism. London: Continuum.

\section{Artikel Jurnal}

Hooker, J. (2009) Corruption from a crosscultural perspective. Cross Cultural Management, 16(3), pp. 251-267.

Nye, J. S. \& Keohane, R. (1971) Transnational relations and world politics: An Introduction. International Organization, 25(3) Summer, pp. 329-349.

\section{Artikel Online}

Bribery without Borders [Online image], Tersedia dalam:<www.nytimes.com/imagepag es/2008/12/21/business/worldbusine ss/20081221_SIEMENS_GRAPHIC.h tml $>$ [Diakses 12 Februari 2012].

Christoff, J. (2004) United Nations: Observations on the Oil for Food Program[Online], United States General Accounting Office.Tersedia dalam: $<$ www.gao.gov/new.items/do4953t.p df $>$ [Diakses 11 November 2011].

Foreign Corrupt Practice Act Reporting Center (2008) Siemens AG Pays USD45O Million to Settle FCPA Bribery Charges[Online], Tersedia dalam: $<$ http://www.foreign-corruptpractices-act.org/foreign-corruptpractices-act-news $/ 5$-siemens-agpays-450-million-to-settle-fcpabribery-charges.html $>$ [Diakses 22 Oktober 2011].

Gray, C. W. \& Kaufmann, D. (1998) Corruption and Development. Finance and Development [Online],3(13) March, pp. 7-10. Tersedia dalam: <http://www.imf.org/external/pubs/f t/fandd/1998/o3/pdf/gray.pdf>

[Diakses 22 Oktober 2011].

Klitgaard, R. (1997) International Cooperation againts Corruption [Online], Internet Center for Corruption Research. Tersedia dalam: <http://www.icgg.org/downloads/co ntributiono2_klitgaard.pdf $>$ [Diakses 27 Februari 2012].

OECD (2011) Convention on Combating Bribery of Foreign Public Officials in International Business Transaction 
and Related Documents[Online], Tersedia dalam:

$<$ www.oecd.org/dataoecd/4/18/3802

8044.pdf $>$ [Diakses 25 September 2011].

Office of the Iraq Programme Oil for Food (2003) About the Programme: Oil for Food [Online], Tersedia dalam: $<$ http://www.un.org/depts/oip/backg round/index.html $>$ [Diakses 28 Februari 2012].

Siemens (n.d) Siemens: From Workshop to Global Player (1847 - 2007)[Online], Siemens Archive. Tersedia dalam:<http://www.siemens.com/his tory/pool/en/history/1847-

1865_beginnings_and_initial_expans ion/company_history.pdf $>$ [Diakses 11 Januari 2012].

The United States District Court for the District of Columbia (2008) Case 1:o8-cr-0o367-RJL [Online], Tersedia dalam:

<http://www.siemens.com/press/poo 1/de/events/2008-12-

PK/DOJ2.pdf $>$ [Diakses 26 September 2011].

Transparency International (2011) Bribe Payers Index 2011 [Online], Tersedia dalam:

$<$ http://www.transparency.de/upload s/media/BPI-2011-REPORT.pdf> [Diakses 8 November 2011]. . (2013) Country Profile - Germany [Online], Tersedia dalam:

<http://www.transparency.org/count ry\#DEU>[Diakses 5 March 2014].

Volcker, P. A., Goldstone, R. J. \& Pieth, M. (2005a) Briefing Paper: Internal Audit Reports on the United Nations Oil-for-Food Programme [Online], Independent Inquiry into the United Nations Oil-for-Food Programme. Tersedia dalam: <http://www.iicoffp.org/documents/

IAD\%20Briefing\%2oPaper.pdf>

[Diakses 14 Januari 2012]. . (2005b) Interim Report [Online], Independent Inquiry into the United Nations Oil-for-Food Programme.Tersedia dalam: $<$ http://www.iic-
offp.org/documents/InterimReportFe b2005.pdf> [Diakses 14 Januari 2012].

. (2005c) The Management of United Nations Oil-for-Food Programme, Volume I - The Report of The Committee [Online], Independent Inquiry into the United Nations Oilfor-Food Programme. Tersedia dalam: <http://www.iicoffp.org/documents/Septo5/Mgmt_V 2.pdf> [Diakses 11 November 2011]. 
